\title{
Examples of the Political Character of International Water Law
}

Gabriel E. Eckstein

Texas A\&M University School of Law, gabrieleckstein@law.tamu.edu

Follow this and additional works at: https://scholarship.law.tamu.edu/facscholar

Part of the Natural Resources Law Commons, and the Water Law Commons

\section{Recommended Citation}

Gabriel E. Eckstein, Examples of the Political Character of International Water Law, in 102 Am. Soc'y Int'I L. Proc. If Water Respects No Political Boundaries, Does Politics Respect Transboundary Waters? 353 (2008).

Available at: https://scholarship.law.tamu.edu/facscholar/350

This Article is brought to you for free and open access by Texas A\&M Law Scholarship. It has been accepted for inclusion in Faculty Scholarship by an authorized administrator of Texas A\&M Law Scholarship. For more information, please contact aretteen@law.tamu.edu. 


\title{
IF WATER RESPECTS NO POLITICAL BOUNDARIES, DOES POLITICS RESPECT TRANSBOUNDARY WATERS?
}

This panel was convened at 1:00 p.m., Friday, April 11, by its moderator, Stephen C. McCaffrey of McGeorge School of Law, University of the Pacific, who introduced the panelists: Alice Aureli of UNESCO; Jutta Brunnée of the University of Toronto; Gabriel Eckstein of Texas Tech; and René Uruena of the University of Helsinki.

\section{Introduction: Politics and Sovereignty over Transboundary GroundWATER}

\author{
By Stephen C. McCaffrey*
}

It is widely known that over a billion people lack access to potable water, and well over twice that number are without adequate sanitation ${ }^{1}$ - the latter situation often being related to the former. It has been calculated that every eight seconds a child dies of water-related causes $^{2}$ - a stunning statistic and an absolutely unacceptable state of affairs.

While much has been made of the prospect of global water shortages, ${ }^{3}$ what is perhaps not so well known is that most of the world's fresh water is shared by two or more states. There are more than 260 international drainage basins, which account for about 60 percent of global river flows. This figure does not include an increasingly important form of this resource, groundwater, much of which also straddles international boundaries. Perhaps this is in part what motivated UN Secretary-General Ban Ki-moon to say, at the World Economic Forum in Davos, Switzerland, in January of this year: "As the global economy grows, so will its thirst ... many more conflicts lie over the horizon," and "too often, where we need water, we find guns." 4

The question for this panel is: "To what extent do political considerations affect the legal relations among states sharing freshwater resources"'? In many ways this is a field that almost invites the intervention of politics: partly because individuals - the Egyptian, Ethiopian or Mexican farmer, for example-may be directly affected by their government's practice regarding shared water resources; and partly because water may be so vital to the very life of a nation that it can be regarded as a matter of national security and thus influence strongly the way that country relates to its neighbors.

But there is another reason that governments might come under the sway of politics where shared fresh water is concerned: some of that water is, at least temporarily, within the boundaries of the state concerned. Thus, water flowing in a river or aquifer from State $A$ to State B is, for a time, within the boundaries of State A. This has on several occasions led states to claim "sovereignty" over the water within their borders-claims that most of them

\footnotetext{
-Distinguished Professor and Scholar, McGeorge School of Law, University of the Pacific.

1 World Health Organization, The Global Water Supply and Sanitation Assessment 20001 (2000).

${ }^{2}$ See, e.g., John J. Brandon, Why a Child Dies Every 8 Seconds, INT'l Herald Trib., May 12, 2001, <http:// www.iht.com/articles/2001/05/12/edbrandon_ed2_.php>.

${ }^{3}$ See, e.g., Streams of Blood, or Streams of Peace, THE Economist, May 1 2008, <http://www. economist.com/ world/international/displaystory.cfm?story_id $=11293778>$.

${ }^{4}$ As quoted in id.
} 
later retracted. ${ }^{5}$ The temptation to make such a claim is understandable, whether it is made by an upstream or a downstream state. ${ }^{6}$ However, the obvious difficulties that can result from an authoritative recognition of "sovereignty" or other forms of absolute rights in either an upstream or a downstream party-let alone both of them--have led both domestic legal systems and international law to reject such an approach.

It is therefore surprising that the United Nations International Law Commission (ILC) has provisionally adopted a set of draft articles that includes the principle of "sovereignty" over shared freshwater resources. This action is particularly remarkable given that the 1997 United Nations Convention on the Law of the Non-Navigational Uses of International Watercourses, ${ }^{7}$ which closely follows an $\amalg C$ draft on which the negotiation of the Convention was based, thoroughly rejects any notion that sovereignty over shared water resources is part of international law. Moreover, the International Court of Justice in the Gabčikovo-Nagymaros Project case also rejected such an idea. The Court referred to a state's "basic right to an equitable and reasonable sharing of the resources of an international watercourse." ${ }^{, 8}$ A right to share in a common resource is difficult, at best, to reconcile with the notion of "sovereignty" over that resource.

The draft articles in question are entitled the Law of Transboundary Aquifers. ${ }^{9}$ The fact that the draft focuses on "aquifers" - water-bearing rock formations-rather than groundwater, may have been the beginning of the problem. Despite the fact that it straddles a boundary, the "rock" itself does not move; it is the water it contains that, in most cases, moves. Thus, while states may claim "sovereignty" over the portion of an aquifer-the rock formation-in their territories, they cannot claim sovereignty over the water contained in the aquifer, which is shared by the states in which the aquifer is located. As proof of this limitation, one need only think of one of the states depleting the aquifer using powerful pumps, or contaminating it with waste deposited in the aquifer's recharge zone. The "sovereignty" of the adversely affected state is of little use as far as such effects are concerned; the state may assert it, but obviously that will not stop the harmful activities affecting the portion of the aquifer over which the other state is "sovereign."

The provision of the draft articles referring to sovereignty is the first article in Part II, "General Principles." Entitled "Sovereignty of aquifer States," Article 3 reads: "Each aquifer State has sovereignty over the portion of a transboundary aquifer or aquifer system located within its territory. It shall exercise its sovereignty in accordance with the present draft articles." 10 The first sentence lets the genie of sovereignty out of the bottle; the second

\footnotetext{
${ }^{5}$ This is true, most infamously, of the "Harmon Doctrine" of absolute sovereignty, stated by U.S. Attomey General Judson Harmon in the context of a dispute with Mexico over the Rio Grande. 21 Op. Att'y Gen. 281 (1898). The dispute was settled in a 1906 treaty entitled Convention concerning the Equitable Distribution of the Waters of the Rio Grande for Irrigation Purposes, 21 May 1906, T.S. No. 455, and the United States later expressly repudiated the Harmon Doctrine. See generally STEPHEN C. MCCAFFREY, THE LAW OF INTERNationaL WATERCOURSES 76-110 ( ${ }^{\text {nd }}$ ed. 2007).

${ }^{6}$ For discussion of the "absolute territorial sovereignty" and " absolute territorial integrity" theories, on occasion advocated by upstream and downstream states, respectively, see MCCAFFRY, id., at 112-135.

${ }^{7}$ U.N. Doc. A/RES/51/869 (May 21, 1997), 36 I.L.M. 700 (1997).

${ }^{8}$ Case Concerning The Gabčikovo-Nagymaros Project (Hungary/Slovakia), 1997 I.C.J. 7, at 54 (Sept. 25).

${ }^{9} 2006$ ILC Report 185, available on the ILC's website, <http://www.un.org/law/ilc/>.

${ }^{10}$ Id. at 202.
} 
sentence cannot put it back in. The notion of sovereignty over shared water is unsupported both in state practice ${ }^{11}$ and in the work of expert groups. ${ }^{12}$ Moreover, it conflicts with the 1997 U.N. Watercourses Convention, since the term "aquifer" is defined ${ }^{13}$ in such a way as to overlap with the definition of "watercourse" in the Convention. ${ }^{14}$ The Commission gives only one reason for this approach: "many states" advocated " $t]$ he need to have an explicit reference in the form of draft article [sic] on the sovereignty of States over the natural resources within their territories ...."15 Space permits only two comments on this justification.

First, to say that a state has sovereignty over the natural resources (forests, coal, iron and other forms of ore, etc.) within its territory is, of course, much different from saying it has sovereignty over shared freshwater resources. But this important distinction seems to have been lost on the Commission. Second, it does not in fact appear that "many" states actually advocated for this proposition. A fairly reliable way to judge this is on the basis of comments submitted by governments on the ILC's draft. The Commission reports that only eighteen states submitted comments on the draft articles and, of those, only six commented on draft article $3 .{ }^{16}$ Of those six states (Austria, Brazil, Cuba, Israel, Portugal and Turkey), three (Austria, Brazil and Turkey) are upstream or predominantly upstream, one (Israel) is upstream on one of the four aquifers it shares, one (Portugal) is predominantly downstream, and one (Cuba) has no international watercourses. Of these states, only Portugal commented that cooperation should be emphasized and that the ILC should "reflect upon whether or not to shift towards a more actual and mitigated doctrine of sovereignty . . .."17 Nevertheless, among the states with international watercourses (including transboundary aquifers) that commented, four does not seem to qualify as "many."

In sum, politics seems to have played a rather strong role in relation to the ILC's Transboundary Aquifers draft. Others on this panel who have been involved in the project in an advisory capacity may well have views on it that differ from those I have expressed here or elsewhere. ${ }^{18}$ But the draft, in its present form, seems to demonstrate that politics may have a strong influence on efforts to develop and codify international law in addition to the role it may play in causing states, from time to time, to disregard international law.

\footnotetext{
${ }^{11}$ None of the authorities cited by the Commission in its commentary to art. 3 deals with transboundary groundwater, or otherwise recognizes "sovereignty" over shared freshwater resources. Id. at 202-203, notes 491-493.

${ }^{12} \mathrm{See}$ Draft articles on the Law of the Non-Navigational Uses of International Watercourses, 1994 Y.B. ILC, v. 2, pt. 2, p. 89; The International Law Association's "Seoul Rules," The Law of International Groundwater Resources, ILA, Report of the Sixty-second Conference, Seoul 1986, pp. 21 and 231-285 (1986); and the highly regarded Bellagio Draft Agreement concerning the Use of Transboundary Groundwaters, contained in Robert D. Hayton \& Albert E. Utton, Transboundary Groundwaters: The Bellagio Draft Treaty, 29 Nat. Res. J. 663, 676 (1989).

${ }^{13}$ Art. 2(a), 2006 ILC Report, supra note 8, at 198.

${ }^{14}$ U.N. Convention, supra note 6, art. 2(a).

152006 ILC Report, supra note 8 , at 202 , para. 1 of commentary to art. 3.

${ }^{16}$ Shared natural resources: comments and observations by Governments on the draft articles on the law of transboundary aquifers, U.N. Doc. A/CN.4/595, available at <http://daccessdds.un.org/doc/UNDOC/ GEN/N08/ 284/80/PDF/N0828480.pdf?OpenElement>.

${ }^{17} \mathrm{Id}$. at 22.

${ }^{18}$ See MCCAFFreY, supra note 5, at 500-502; and McCaffrey, Stephen C., 'Comments on the International Law Commission's Draft Articles on the Law of Transboundary Aquifers (2006)' (Mar. 30, 2008), available at SSRN: <http://ssm.com/abstract=1114988>.
} 


\title{
Transboundary Aquifers: International Law and Politics?
}

\author{
By Alice Aureli and Raya M. Stephan ${ }^{*}$
}

Groundwater contained in aquifer systems is the world's most extracted raw material ${ }^{1}$ and represents the most significant as well as the safest source of drinking water. In the late sixties the science of hydrogeology was specifically developed in order to study and improve the understanding of aquifer systems, whose characteristics differ from those of surface water bodies. Since this time UNESCO's International Hydrological Program (IHP) has devoted particular attention to these systems.

The studies conducted by UNESCO-IHP have demonstrated that significant quantities of groundwater resources can be found in transboundary aquifers in each of the regions of the world. We envisage that in the coming years several regions will face severe water scarcity conditions. As a result, competition for these shared resources could increase and become a source of conflict. In 2000, UNESCO-IHP launched the International Shared Aquifer Resources Management project (ISARM) to conduct a worldwide inventory and assessment of these systems. Considering the importance of these systems for human development and the natural environment, it appears that until recently there has been an imbalance in the attention paid by international law and politics to transboundary aquifers. While research on transboundary river basins and lakes has been taking place for many years, the same cannot be said for transboundary aquifers. The UNESCO ISARM project highlights a general need for research into politics and international law surrounding this underground component of the hydrological cycle. The project has since established successful cooperation between countries sharing aquifer systems in different regions of the world. It has also provided technical and scientific advisory to the UN International Law Commission (UNILC) in the preparation of the draft articles on the law of transboundary aquifers.

\section{The UNESCO International Transboundary Aquifer Resources MANAGEMENT PROJECT (ISARM)}

Groundwater contained in aquifer systems is the main water supply source in several megacities (e.g. Mexico City, São Paulo, and Bangkok) and provides nearly 70 percent of the piped water supply in the European Union. Agriculture and particularly irrigation systems in many parts of the world (e.g. India, Northern Africa, and Western Asia) strongly depend on groundwater resources. Until recently no quantitative or qualitative groundwater inventory was available and the relevance of transboundary aquifers in the global water balance was unknown. Indeed, until 2002 no regional or global estimation existed for transboundary aquifers.

In the year 2000, the Intergovernmental Council of UNESCO-IHP responded to this knowledge gap during its $14^{\text {th }}$ Session (23-25 June 2000). Today, IHP is unique in that it is the only intergovernmental process on water sciences; each phase of the program lasts for six years and its activities are defined by its Member States. The Members States of UNESCOIHP's Intergovernmental Council are elected at the General Conference of UNESCO, and the delegates who participate in the Council are nominated by their respective governments.

\footnotetext{
*Dr Alice Aureli, UNESCO International Hydrological Programme (IHP), IHP-Groundwater Resources, UNESCO Paris; Ms. Raya M. Stephan, UNESCO Consultant, International Law, UNESCO Paris.

' ZeKSTER, I. and EvereTT, L. (Eds). 2004. Groundwater Resources of the World and Their Use. IHP-VI, Series on Groundwater No. 6. UNESCO, Paris.
} 
The Council meets every two years to set up directives and priorities to UNESCO on the implementation of global, regional and national water-related activities. The IHP program is thus a political process driven by sovereign states. Within this context, therefore, it was essential that the IHP Member States recognized the lack of knowledge on transboundary aquifers and adopted a resolution to promote their study and subsequently to launch a worldwide inventory of them.

The aim of the UNESCO-IHP Member States, in particular from arid-zone countries where groundwater is often the only source of fresh water, was to ask UNESCO to lead a global effort to fill this gap in the knowledge about these systems and their occurrence as well as their relevance to the overall global water balance and economy. Therefore at the 14th Session of the Intergovernmental Council the Member States adopted Resolution XIV-12 launching the ISARM project with the view of promoting studies related to transboundary aquifers. The Council invited Member States to facilitate regional cooperation and encourage other UN Agencies to provide their support. ISARM is a multi-disciplinary project that has identified five focus areas in the management of transboundary aquifers: scientifichydrogeological scope; and legal, socio-economic, institutional, and environmental aspects. ${ }^{2}$

The UNESCO ISARM project operates in each continent in coordination with Member States and various intergovernmental, governmental and international partners. UNESCO and the United Nations Economic Commission for Europe (UNECE) are working jointly to carry out the inventory of transboundary aquifers in Western Europe, South Eastern Europe and Central Asia. The initial results recognize more than one hundred shared aquifers. Since 2003 UNESCO and the Organization of American States (OAS) have completed a comprehensive inventory of transboundary aquifers in the Americas. ${ }^{3}$ Following the UNESCO ISARM approach, the ISARM of the Americas project has in its first phase collected data regarding the hydrogeological characteristics of main transboundary aquifers and their use. Since January 2006 the National Coordinators of the countries concerned jointly identified sixty-eight transboundary aquifers: twenty-nine are located in South America, eighteen in Central America, seventeen in North America and four in the Caribbean. Evaluations showed that some of the most important aquifers in South America are transboundary systems.

The second phase assessed and analyzed the institutional and legal frameworks of transboundary aquifers in the region, the results of which were published by UNESCO in April 2008. The third phase, initiated in 2007 , focuses on the sustainable socio-economic and environmental aspects of transboundary aquifers for which results should be published in 2009. The close cooperation between country representatives, UNESCO and OAS has allowed for the preparation of the first comprehensive continental assessment of transboundary aquifers with the result of providing valuable tools to decision-makers of the region for the improvement of the understanding and management of these resources. In fact, the cooperative and participative process undertaken in the ISARM Americas project was critical to its success. Preliminary inventories have also been initiated in Africa and in East Asia but will take a few more years to be fully implemented.

\footnotetext{
${ }^{2}$ S. Puri, (Ed.), Appelgren, B., Arnold, G., Aureli, A., Burchi, S., Burke, J., Margat, J. and Pallas, P. 2001. Internationally Shared (Transboundary) Aquifer Resources Management: Their Significance and Sustainable Management. A Framework Document. IHP-VI, Series on Groundwater No. 1. UNESCO, Paris.

${ }^{3}$ ISARM Americas: Da Franca Ribeiro dos Anjos, N., Miletto, M., Donoso, M. C., Aureli, A., Puri, S., VAN DER GUN, J., TUICHNEIDER O. and RIVERA, A. 2007. Acuíferos transfronterizos en las Américas. Evaluación Preliminar. UNESCO-IHP/OAS, Montevideo/Washington D.C.
} 
The question remains, however, of whether technical and scientific efforts carried out in cooperation and coordination with the Member States are sufficient evidence to confirm that the political process is taking due consideration of transboundary waters. This process is certainly a very encouraging example that should continue in other continents and could lead to a real improvement in cooperation and awareness both in the legal and political communities.

\section{The Draft Articles on the LaW of Transboundary Aquifers}

The UN World Water Assessment Program (WWAP), the mechanism established by the UN Secretary General that coordinates the contribution of twenty-three UN agencies working in fields related to water resources, has recognized that the water crisis is one of governance and that water is a shared responsibility. The lack of political consideration and appropriate financing for groundwater resources is inappropriate considering the importance of groundwater for human development and environmental cycles. Also considering that exploitable groundwater resources contained in the transboundary aquifer systems are under the surface of all regions of the planet-some frequently utilized and some not yet exploited-the political and legal attention and understanding of these systems should be improved. Europe is the region that is better equipped with regional legal settings on transboundary water resources.

Both the UNECE Convention on the Protection and Use of the Transboundary Watercourses and International Lakes concluded in 1992 and the European Union Water Framework Directive of 2000 (expanded in 2006 to the daughter directive dealing with groundwater resources) provide the member countries with recommendations and a set of rules and regulations on the use and management of these systems in which the environmental protection regulations are particularly strict.

While provisions on groundwater exist in many binding and non-binding legal instruments, there is the need to deal comprehensively with transboundary aquifer systems by addressing their specific characteristics. However, in 2002, the UN International Law Commission (UNILC) in charge of the codification and progressive development of international law added the topic of Shared Natural Resources to its program. The Commission divided the program into three sub-topics: transboundary groundwaters, oil and gas. The Special Rapporteur decided to adopt a step-by-step approach and began with "transboundary groundwaters." Within the framework of its ISARM project, UNESCO-IHP has, since 2003, upon the request of the Special Rapporteur, provided scientific and technical advice to the UNILC on issues related to hydrogeology. It did so by inviting, coordinating and supporting the contributions of international experts, as well as international, regional and national institutions. A series of meetings and briefings to provide guidance on the science of hydrogeology were held in Paris, Tokyo, and Geneva at the UNILC Headquarters and in New York at the 6th Committee of the UN General Assembly.

In his third report (2006) the Special Rapporteur submitted a full set of draft articles, which were adopted by the UNILC on first reading. Furthermore, the ILC decided, in accordance with its statute, to request the UN Secretary General to transmit the draft articles to governments for comments and observations to be submitted the beginning of 2008 .

Overall the comments presented (oral and written) by the countries are positive. They acknowledge the scientific and technical background on which the draft articles have been drawn and consequently recognize the importance of transboundary aquifers and the need to adopt rules to govern their management. Most of the countries recognizing sharing aquifer 
resources looked at the work of the ILC very positively. In particular they expect the establishment of general principles, which could guide states in the negotiation of regional agreements of a more specific nature. Countries acknowledge the need for a flexible and open text that could contribute to raising awareness about the subject and heightening the priority of the issue in the agenda of the states and encouraging them to negotiate regional agreements.

The process leading to the establishment of rules of international law regarding transboundary aquifers is slow, but it seems that this process is now finally in place.

\section{CONCLUSIONS}

If competition for the visible transboundary surface waters (rivers, lakes, etc.) is already evident in all continents, competition for the hidden blue gold contained underground the surface has only just started. UNESCO-IHP is cooperating with the countries sharing groundwater resources to better define the technical, economic and social challenges related to the management of these resources.

Education and cooperation is at the root of our changing approach to the peaceful management of transboundary aquifer systems. The central questions are: how can cooperation be improved and how can water related conflicts be prevented? How can socio-economic, cultural, ecological, and other values be incorporated into the planning and management of shared groundwater resources under conditions of water stress? UNESCO-IHP ISARM program in coordination with other UN agencies is today looking to set up educational tools and incorporate clear mechanisms for conflict prevention as a prerequisite for effective longterm transboundary aquifers management.

Through intergovernmental processes such as UNESCO-IHP ISARM project, countries are more prepared to accept the sharing of information, to discuss adequate institutional frameworks and laws and find a common approach.

Thus we hope that the international law on transboundary aquifers continues to progress and expect that complementary political processes will evolve to ensure its successful implementation.

\section{Law and Politics in the Nile Basin}

\section{By Jutta Brunnée*}

Perhaps one of the best settings in which to examine the question posed in the panel title and attendant questions about the role of international law in the context of transboundary waters, may be furnished by the issues surrounding cooperation among riparians in the Nile Basin.

The Nile flows through Northeastern Africa for almost 7,000 kilometers, draining roughly three million square kilometers of land and supplying water to nine basin states, many of which are experiencing rapid population growth. Approximately 85 percent of the Nile's waters originate in Ethiopia. The Blue Nile (draining Lake Tana in Ethiopia) and the White Nile (originating in Lake Victoria and flowing through Sudan) meet at Khartoum. The river then crosses into Egypt and drains into the Mediterranean Sea. ${ }^{1}$ It is Egypt's primary source

\footnotetext{
- Professor of Law and Metcalf Chair in Environmental Law, Faculty of Law, University of Toronto.

${ }^{1}$ See Arun P. Elhance, The Nile Basin, in Hydropolitics In the Third World: Conflict and CoOperation IN INTERNATIONAL RIVER Basins 53 (1999).
} 
of water. ${ }^{2}$ Given rapid population growth in the basin, increasing demand for water and climatic changes, water scarcity and competition for water are central concerns. ${ }^{3}$ Several of the basin countries, notably Burundi, Kenya and Rwanda, already suffer from water scarcity. Egypt and Sudan are projected to experience water scarcity by 2025 , Tanzania and Sudan by $2050 .^{4}$

Historically, relations between Nile basin states have been tense. Due to political differences, relating to the Nile as well as to broader geopolitical issues, past discourse among riparian states has tended to be bellicose. ${ }^{5}$ But notwithstanding the tensions and the vital importance of Nile waters for some of the riparians, there has not been open conflict. Indeed, over the last ten to fifteen years, the discourse has shifted away from the specter of water wars.

Still, significant differences remain to be resolved regarding the Nile waters, including most prominently those concerning the respective entitlements of Egypt and Sudan. Indeed, the main existing agreement regarding Nile waters is a 1959 treaty between Egypt and Sudan. ${ }^{6}$ No basin-wide agreement exists as of yet.

In a paper published in 2002, my colleague Stephen Toope and I considered the role that law has played in this setting, and could play in shaping the interaction among the Nile basin states. ${ }^{7}$ This panel provides a welcome opportunity to revisit the arguments presented in that paper and to consider the trajectory of riparian relations since.

At first blush, it may be tempting to say that international law has only a limited role to play in the Nile basin. At best, law will follow politics and interests, entering the picture only once political agreement has been reached. We argued that law is more than a "formalizer" or a device for creating "hard" entitlements and enforceable rules. It is better understood as an ongoing generative activity, as a distinctive practice-a practice that is about building and sustaining shared norms, and building and maintaining legality.

In making this argument, we draw on Lon Fuller's account of law as distinguished by adherence to certain internal criteria of legality, such as generality, promulgation, nonretroactivity, clarity, and congruence between rules and official action. ${ }^{8}$ These features are crucial to generating distinctively legal legitimacy and a sense of commitment-what Fuller called "fidelity" - among participants in the legal system. They are at the heart of the phenomenon of legal obligation. They account for law's binding effect because actors' ability to rely on law in their decision-making, and their commitment to the law, is fostered by adherence to these requirements. ${ }^{9}$ In short, law is not hierarchical ordering. It is not a oneway street. It cannot be decreed or imposed. It exists only when actors collaborate to build shared understandings and when their interactions actually embrace the requirements of

\footnotetext{
${ }^{2}$ See Aaron Schwabach, The United Nations Convention on the Law of Non-Navigational Uses of International Watercourses, Customary International Law, and the Interests of Developing Upper Riparians, 33 TEXAS INT'L L. J. 257, 263 (1998).

${ }^{3}$ Experts speak of water scarcity when less than 1,000 cubic meters of renewable freshwater are available per person per year. See Malin Falkenmark, Rapid Population Growth and Water Scarcity: The Predicament of Tomorrow's Africa, 16 Population \& Dev. Rev. 81, 84 (1990).

${ }^{4}$ See Sam L. Laki, Management of Water Resources in the Nile Basin, 5 INT'L J Sustainable Dev. \& WorLd ECOLOGY 288, 289 (1998).

${ }^{5}$ See Ashok Swain, Ethiopia, the Sudan, and Egypt: The Nile River Dispute, 35 J. Mod. Afr. STud. 675 (1997).

${ }^{6}$ Agreement Between the Republic of the Sudan and the United Arab Republic for the Full Utilization of the Nile Waters, 8 November 1959, 453 UNTS 6519 51, (entered into force Dec. 12 1959).

7 Jutta Brunnee and Stephen J. Toope, The Changing Nile Basin Regime: Does Law Matter?, 43 HIIJ 105 (2002).

${ }^{8}$ See Lon L. Fuller, The Morality of Law 46-91, 155 (rev. ed. 1969).

${ }^{9}$ For an extended discussion, see Jutta Brunnée \& Stephen J. Toope, International Law and Constructivism: Elements of an Interactional Theory of International Law, 39 CoL. J. TRANSNAT'L L. 19, 43-64 (2000).
} 
legality. Law is quite literally work in progress, consisting in a practice of legality that must be instantiated and maintained with care.

Drawing on constructivist IR theory, ${ }^{10}$ we suggest that law has the potential to shape the interests and even identities of states; that it both enables and constrains international discourse by establishing what counts as persuasive argument; and that its specific legitimacy (if built as described above) enhances persuasiveness. However, law's impact is not necessarily positive. It can also perpetuate conflictual practices or reinforce insistence on entrenched positions, ${ }^{11}$ as it seems to have done throughout much of the history of international lawmaking regarding Nile waters. The apparent failure of water law in the Nile region was in large measure a matter of misplaced faith in formal rules, and hard entitlements. For example, the 1959 agreement contained fixed allocation quotas, no option for renegotiation and alteration in light of new circumstances. It purported to share the waters of the Nile between only two of the riparians, thus undercutting basin-wide trust building. Ethiopia, for example, never recognized the 1959 apportionment. ${ }^{12}$

Such rigid entitlements tend to foster competitive arguments, rather than cooperative exchange. The two core principles of international water law, the equitable utilization principle and the no harm rule, and the long-standing debate about which of them takes priority, ${ }^{13}$ further complicate the picture. The opposition between these two principles promotes adversarial roles and also tends to promote absolute positions being taken by upstream and downstream states, respectively.

Overcoming the barriers to cooperation in the region has been a slow process. Basin states began to take tentative steps towards information sharing and engagement on technical issues in the early 1980s. Various international actors, such as the World Bank, UNDP and FAO, have worked patiently to assist basin states in moving beyond confrontational paradigms and to foster confidence-building and basin-wide cooperation. That cooperation has been built from the ground up, beginning mostly with technical activities and exchanges, workshops at the bureaucrat level, and so forth. ${ }^{14}$ Out of a framework for such technical cooperation grew the 1995 Nile River Basin Action Plan, one component of which was the development of a basin-wide framework for legal and institutional arrangements. ${ }^{15}$ In 1999, the Nile Basin Initiative (NBI) was launched to promote sustainable socio-economic development through "equitable utilization of, and benefit from, the common Nile Basin water resources." 16 It was conceived as an interim arrangement designed to facilitate permanent cooperation, including through the development of a legal framework. The NBI produced a "shared

\footnotetext{
${ }^{10}$ For an overview, see e.g., Emanuel Adler, Constructivism in International Relations, in HANDBOOK OF INTERNAtional Relations 95 (Walter Carlsnaess, Thomas Risse and Beth Simmons, eds., 2002).

${ }^{11}$ See Alexander Wendt, Collective Identity Formation and the Intermational State, 88:2 AM. PoL. SCI. REv. 384, 389 (1994) (speaking generally of social norms).

12 See also Pamela LeRoy, Troubled Waters: Population and Water Scarcity, 6 Colo. J. INT'L ENVTL L. \& PoL'y 299, at n. 75 (1995).

${ }^{13}$ For an overview, see Jutta Brunnée \& Stephen J. Toope, Environmental Security and Freshwater Resources: Ecosystem Regime Building, 91 AJL 26, 40-1, 60-63 (1997).

${ }^{14}$ For a detailed account of this evolution see Brunnée \& Toope, supra, note 7, at 131-144.

${ }^{15}$ See TECCONILE, Nile River Basin Action Plan (1995), at vii. TECCONILE stands for "Technical Cooperation for the Promotion of the Development and Environmental Protection of the Nile Basin."

${ }^{16}$ See Nile Basin Initiative, NBI Background-Objectives, <http://www.nilebasin.org/index.php? option= com_content\&task=view\&id=13\&Itemid=42> (last visited June 6, 2008).
} 
vision" program for basin-wide action, and various subsidiary programs for joint-development programs at the sub-basin level. Significantly, unlike previous initiatives, the NBI engaged all basin states, including Ethiopia. ${ }^{17}$

In 2002, our hypothesis was that the NBI, in all of its "looseness" and "softness," was precisely what was needed to build law from the ground up, to cultivate a foundation of shared understandings - - of norms that are embraced by all relevant actors, and that shift the frame of reference from competition to the gradual building of collective interests and identities of riparian states also as basin states. It is in this way, then, that legal norms can come to shape politics. To be clear, "shared understandings" need not be substantive in nature. Equally important is a genuinely shared sense of the issues at hand, and that a permanent framework - a legal framework-is required, or even desirable, and a solid foundation of procedural understandings.

Six years later, a basin-wide legal framework has not been adopted. That said, and while significant obstacles remain, a number of developments suggest that the conclusion of such an agreement is not out of the question. For present purposes, it suffices to highlight two of the key developments.

First, the broader normative context has gradually shifted, as efforts have been made to resolve the tension between the equitable utilization and no harm principles. Some of this shift finds expression in the UN Convention on the Law of Non-Navigational Uses of International Watercourses. ${ }^{18}$ The Watercourses Convention attempted to draw the two principles together in such a way as to make it impossible to make arguments under one principle while disregarding arguments based on the other. ${ }^{19}$ Nonetheless, states continued to maintain different views on the relationship between those principles, a fact seen by many observers as a central reason why the convention has not yet attracted sufficient ratifications for entry into force. ${ }^{20}$ Yet there does appear to be a slow evolution towards a framework of rules in which neither principle could be applied in isolation from the other. For example, in an important departure from its influential 1966 Helsinki Rules, the International Law Association (ILA) adopted the 2004 Berlin Rules on Water Resources, which take into account inter alia developments in international environmental law and the adoption of the UN Watercourses Convention. ${ }^{21}$ Whereas the Helsinki Rules had strongly emphasized the principle of equitable utilization, the Berlin Rules give pride of place to the protection of the aquatic environment, relating the management of waters to the protection of the surrounding environment. According to Articles 12 and 16 of the Berlin Rules, each basin state is obliged to manage the waters of an international drainage basin in an equitable and reasonable manner. The term "manage" encompasses "development, use, protection, allocation, regulation, and control of waters." 22 Importantly, this management requirement is subject to "having due regard for the obligation not to cause significant harm to other basin states." ${ }^{, 23}$ In other words, the right to equitable utilization of transboundary water resources now carries with it certain

\footnotetext{
${ }^{17}$ See Ethiopia, Sudan, Egypt to join hands in water project, XINHUA NEws AGENCY, Sept. 16, 1999 (file with the author).

${ }^{18}$ U.N. Convention on the Law of Non-Navigational Uses of International Watercourses, U.N. Doc. A/RES/51/ 229 (May 21, 1997), reprinted in 37 I.L.M. 700 (1998).

${ }^{19}$ See Brunnée \& Toope, supra, note 7, at 151-152.

${ }^{20}$ See e.g. Salman M. A. Salman, The Helsinki Rules, The UN Watercourses Convention and the Berlin Rules: Perspectives on Intermational Water Law, 23 INT'L J. WATER ResouRCES DEv. 625, 634 (2007).

${ }^{21}$ ILA, Report of the Seventy-First Conference - Berlin 334, at 339 (London: ILA, 2004).

22 Id. at 345 (Article 3.14).

${ }^{23}$ Id., at 361 (Article 12.1).
} 
duties in the use of the waters. ${ }^{24}$ Indeed, in subjecting the two principles to one another, the Berlin Rules treated them as equal. ${ }^{25}$

Meanwhile, Nile Basin states have continued to collaborate on a range of projects within the NBI. Activities range from high-level ministerial meetings to regular "grassroots" training sessions, ${ }^{26}$ to the distribution of sizable funds to sub-national institutions, ${ }^{27}$ to the declared goal of member states to transform the NBI into a new Nile Basin Commission, and to conclude a long-term agreement on the use of Nile waters. ${ }^{28}$ An expert group began its work on the development of such a framework in 1997. According to recent press reports, a draft "Nile Cooperative Framework Agreement" is now almost finalized. ${ }^{29}$ Seven of the nine basin states are supportive of the current draft, while Egypt and Sudan remain unwilling to agree to the text. Aside from lingering debates about the role of the equitable utilization and no harm principles, a provision on "water security" in the basin appears to be most contentious. ${ }^{30}$ Reportedly, Article 14 of the draft obligates basin states, while bearing in mind the equitable utilization and no harm principles, "not to significantly affect the water security of any other Nile Basin State." ${ }^{, 31}$ For Egypt and Sudan, this provision remains problematic, as it is seen to affect the allocation arrangement between them. ${ }^{32}$

It is still too early to predict whether or not the ongoing basin-wide engagement will erode the insistence of Egypt and Sudan on the rights enshrined in the 1959 treaty. Arguably, the move towards a basin-wide legal framework undercuts the legitimacy of what is a bilateral treaty. Similarly, the importance of the gradual shift in the broader normative framework for interactions among Nile riparians is not to be underestimated. After all, it provides a frame of reference for legal arguments made by basin states. It appears as if the normative development sketched above has come to be woven into the efforts to elaborate a basinwide legal framework for the Nile, notably into its approach to the equitable utilization and no harm principles. Whether these normative underpinnings will come to be shared by all basin states, and will come to shape their political engagement, remains to be seen. Much progress has been made in moving basin states onto a cooperative path, and it seems fair to say that patient norm building efforts have played a significant role in this context. What can be said with certainty is that the developments in the Nile Basin are worth watchingthey provide a fascinating case study for all those interested in the interplay between (water) law and politics.

\footnotetext{
${ }^{24} I d$., at 362 .

${ }^{25}$ Salman, supra note 20 , at 636 .

${ }^{26}$ See, e.g., Nile Basin Initiative, Nile Technical Advisory Committee (Nile TAC) Meeting Held in Entebbe, <http:// www.nilebasin.org/index.php?option=com_content\&task=view\&id=59\&Itemid=113> (last visited Mar. 10, 2008).

${ }^{27}$ Nile Basin Initiative, Fourteen Institutions from the Nile Basin Countries to Receive $\$ 50,000$ each from the $\mathrm{NBI}$, <http:/www.nilebasin.org/index.php?option=com_content\&task=view\&id=71\&Itemid=113> (last visited Mar. $10,2008)$.

${ }^{28}$ Nile Basin Initiative, Nile Commission to Succeed Nile Basin Initiative, 21 May 2007, <http://cbsi.nilebasin.org/ index.php?option=com_content\&task=view\&id=19\&Itemid=28> (last visited Mar. 10, 2008).

${ }^{29}$ Edwin Musoni and Agencies, Africa: Rift Widens Over Nile Basin Pact as Egypt, Sudan Remain Reluctant, THE New Trmes (Kigali), Feb. 29, 2008, <http://allafrica.com/stories/200802290213.html>.

${ }^{30} \mathrm{Id}$.

${ }^{31} \mathrm{Id}$.

32 Joseph Ngome, Clause Holds Key to New Nile Treaty, The Nation (Nairobi), Mar. 28, 2008, <http://allafrica.$\mathrm{com} /$ stories/200803280008.html>.
} 


\title{
Examples of the Political Character of International Water Law
}

\author{
By Gabriel Eckstein ${ }^{* \dagger}$
}

In this brief paper, I suggest that the substantive principles of international water law have such a political character that they may be viewed more properly as tools of politics and international relations rather than those of a legal regime. In support of this proposition, I review two principles: equitable and reasonable utilization and sovereignty. The former is considered in the general context of international water law, while the latter is assessed in relation to the law applicable to transboundary groundwater resources.

In considering the differences between substantive principles of law versus those of politics and international relations, two interrelated questions to consider are: whether the principles are intended for judicial application, or intended for state relations; and whether the principles are intended to be assessed objectively or subjectively. A principle may be viewed as a tool for politics or international relations when it is employed ex ante and designed to further relations between states. Moreover, it is typically applied subjectively in relation to the positions of the states that assert principle. In contrast, a legal principle is designed to be applied ex post in an effort to determine whether the principle was violated. As such, it is applied objectively, most often by a tribunal or arbiter.

In the case of war crimes and international criminal law, for example, the principles asserted are clearly intended to be applied objectively by a tribunal ex post. In such situations, an independent arbiter is expected impartially to review the facts of the case, assess and interpret the applicable law, and then determine whether a violation occurred. In contrast, while they certainly could be assessed objectively ex post, substantive international water law principles are designed to be implemented ex ante-in the course of negotiations. Instead of determining fault or liability, they are designed to encourage cooperation and prevent discord among the states. As such, international water law principles may be viewed more appropriately as tools of the political process between states negotiating over transboundary waters rather than tools of an adjudicatory process.

For example, the principle of equitable and reasonable utilization is regarded as one of the bedrock legal norms of international water law. It is recognized in Articles 5 and 6 of the 1997 Convention on the Non-navigational Uses of International Watercourses ${ }^{1}$ as well as other international instruments. In considering the principle and the factors used to ascertain its implementation, it certainly could be applied objectively after-the-fact by a tribunal in determining whether a transboundary body of water was equitably and reasonably used or allocated. ${ }^{2}$ Yet, it seems unlikely that the principle and the factors were formulated as a means for punishing a state for its inequitable use of transboundary waters. Rather, it may be more likely that they were devised as tools for negotiating and facilitating cooperation and achieving equitable and reasonable utilization of shared transboundary waters.

The principle and its related factors are always asserted in a negotiation over transboundary waters. For example, states often argue equity and reasonableness in terms of the needs of

\footnotetext{
* George W. McCleskey Professor of Water Law and Director of the Center for Water Law \& Policy, Texas Tech University; Director of the Internet-based International Water Law Project.

${ }^{\dagger}$ This paper is based on a presentation given at the $102^{\text {nd }}$ Annual Meeting of the American Society of International Law, Washington, DC, Apr. 11, 2008.

${ }^{1}$ U.N. Convention on the Law of Non-Navigational Uses of International Watercourses, 21 May 1997, UN. Doc. A/RES/51/229 (1997), reprinted in 37 ILM 700 (1998).

${ }^{2}$ See e.g. Case Concerning The Gabèikovo-Nagymaros Project (Hungary/Slovakia), 1997 I.C.J. 7 (Sept. 25).
} 
their population, the efficiency of their use, the availability of other sources of freshwater, and other points. Eventually, where the states reach an accord, the result is an ex ante and subjective determination of what the states agree is equitable and reasonable use of the transboundary waters at issue.

For example, the 1944 treaty between the United States and Mexico over the waters of the Rio Grande allocates the water of the river and its tributaries using specific allocations. In recent years, concerns have been voiced that these numbers provide an inequitable benefit for the United States at the expense of Mexico. Nonetheless, since the two countries negotiated and agreed upon this precise allocation scheme, who is to say that the numbers contained in the treaty do not constitute an equitable and reasonable allocation of the river, at least from the perspectives of the two riparians? The recognition of this fact offers considerable evidence of the political character of this substantive international water law principle.

Turning to the example of sovereignty, Article 3 of the Draft Articles on Transboundary Aquifers ${ }^{3}$ provides that " [e]ach aquifer State has sovereignty over the portion of a transboundary aquifer or aquifer system located within its territory." Significantly, there is no parallel provision in the Watercourse Convention. Considering this inconsistency, a logical question arises: why would states emphasize sovereignty in the context of transboundary aquifers but not in the context of transboundary watercourses? It is noteworthy that Draft Article 3 was adopted in response to numerous voices on the UN International Law Commission (UNILC) and the UN $6^{\text {th }}$ Committee that advocated for an explicit reference to the notion of sovereignty over groundwater resources. ${ }^{4}$ In contrast, while similar voices were heard during the development of the Watercourse Convention, no equivalent provision was adopted into that treaty.

When dealing with groundwater, many states and individuals around the world regard the resource as uniquely different from surface waters such that it requires a distinctive regulatory regime, regardless of whether or not there is a logical or scientific underpinning to that assumption. For example, groundwater is often compared to resources like oil and gas, in part, because of its fluidic characteristic and subsurface location. In turn, these characteristics, as well as a fundamental misunderstanding of the science of groundwater, often color many people's understanding of the resource resulting in a belief that groundwater is mysterious and incapable of being regulated. This misunderstanding is evident even today in the United States where many U.S. states continue to rely on decisions dating back to the 1800 s in which courts regularly concluded that groundwater is so mysterious and secretive that it is properly related to the "occult.", 5

While space limits the presentation of other examples of the fallacy of this perspective, suffice it to say that there is a widespread understanding, especially among decision-makers, that groundwater is somehow different from surface water and should be subjected to a state's sovereignty in a way that is not appropriate for surface waters. The result is a decision based on the politics of sovereignty and resource management rather than law or science. Significantly, Ambassador Chusei Yamada-the UNILC Special Rapporteur responsible for

\footnotetext{
${ }^{3}$ Report of the International Law Commission on the Work of its Fifty-Eighth Session, Shared Natural Resources, 61 st Session, Supplement No. 10 (AV61/10) (2006), II 72, at 184.

${ }^{4}$ Gabriel Eckstein, Commentary on the U.N. International Law Commission's Draft Articles on the Law of Transboundary Aquifers, 18 CoLo. J. INT'L ENVTL. L. \& Pol'y 538, 553, 560-561 (2007).

${ }^{5}$ See Sipriano v. Great Spring Waters of Am., 1 S.W. 75 (1999) (upholding the rule established in Houston \& Texas Central RR. Co. v. East, 81 S.W. 279 (1904), which was based on Frazier v. Brown, 12 OH 294 (1861), one of a number of cases characterizing groundwater as akin to the "occult").
} 
shepherding the development of the Draft Articles-has taken the position that while it may be erroneous, this perception is so prevailing that it represents customary international law. ${ }^{6}$

The notion that international law could be used as political tool is not necessarily a new concept. Yet, international water law appears to take this a step further by embracing principles that may be more applicable in a subjective political process rather than an objective judicial environment. This appears evident in substantive international water law principles like equitable and reasonable utilization and sovereignty.

\section{The Boundaries of THE LaW OF INTERnational Watercourses}

\section{By René Uruena*}

Our panel seeks to examine the politics of the law of international watercourses. In this regard, I would like to propose, first, an alternative reading as to why politics enters the equation in international water law. Then, I will try to map three of the mechanisms through which this move is performed, and I will end up with some conclusions that, I hope, will be of use for those interested enough to drop by-and those consulting the proceedings at a later stage.

That water law is a political undertaking is nothing to write home about. Though the notion that the discipline is a mainly technical craft still finds its way into some of the literature, there seems to be a growing agreement that politics is at the heart of our discipline, and this very panel bears witness to that point. The question, then, is not whether, but why and how this is so. What follows is an effort to provide an answer to those questions.

Why is international water law a political undertaking? One standard answer is that water is a fundamental, scarce and thus highly valuable resource. It is only logical that its regulation becomes a power struggle, and consequently a matter of politics. ${ }^{1}$ This explanation is partially correct, but it fails to grasp the specificities of water law, as compared to other fields of international law. Water law is, by default, perceived as a means to an end. Its raison d'être is to be useful for something else: protecting the resource, or preventing conflict between riparian states, among others. Such an openly instrumental view of law would be a scandal in other areas as, for example, human rights. ${ }^{2}$ However, it does go without much debate in our discipline. And if law is not up to the task, then we can appeal to others means, such as economical incentives, lobbying, or perhaps even shaming water polluters into changing their ways.

The problem is that, although there is widespread agreement on the instrumentality of international water law, there is much less agreement on what precisely that instrument is for. What is it that we strive for through the law of international watercourses? Consider the Preamble of the 1997 Convention on the Law of the Non-navigational Uses of International Watercourses (the " 1997 Convention") 3 , which expresses the conviction that the instrument would ensure the "utilization, development, conservation, management and protection of

\footnotetext{
${ }^{6}$ Gabriel Eckstein, Unofficial notes of meeting of UNESCO advisory group to Ambassador Chusei Yamada, Tokyo, Japan, January 28-30, 2008 (on file with author).

Research Fellow, Centre of Excellence in Global Govemance Research (University of Helsinki).

${ }^{1}$ For a recent example, see UNDP, 2006 Human Development Report "Beyond Scarcity: Power, Poverty And The Global Water Crisis"' (2006).

${ }^{2}$ See Annelise Riles, Anthropology, Human Rights, and Legal Knowledge: Culture in the Iron Cage, 108 AM. ANTHROPOLOGIST 52 (2006).

${ }^{3}$ G.A. Res. 51/229, Annex. U.N. Doc. A/51/49.
} 
international watercourses and the promotion of the optimal and sustainable utilization for present and future generations." Clearly, all are worthy goals, but they are fairly general in their wording. International water law is unapologetic in its instrumentality, but unclear in its objectives. It seems to provide no distinctively legal criterion for deciding which policy objectives are worth pursuing, and which others are not. Consequently, legal debate on international water resources becomes a discussion on water policy, and adjudication turns into a political act. This subtle paradox seems to explain why, beyond water's sheer value, politics is at the heart of our field.

\section{Three Mechanisms of Politicization}

Now, let us turn to the how. I would like to map here three ways in which the law of international watercourses becomes influenced by its political context. The first one is a turn to reasonability, as embodied in the equitable utilization principle. The second one is, to put it shortly, our "disciplinary neighbors," or the problem of fragmentation in international water law. Finally, the third mechanism of politicization is the procedural shape taken recently by several disputes related to the resource. Let's take a brief look at each of them.

First, we find the turn to reasonability. The law of international watercourses became the dominion of reasonability as the principle of equitable and reasonable utilization became its comerstone. ${ }^{4}$ This is not to say that the principle is inappropriate; quite the contrary, it is perhaps the only workable approach to the matter, as is evidenced by the origins and evolution of Article 5 of the 1997 Convention. ${ }^{5}$ However, the principle does not solve concrete cases by itself. Only its application in a given context solves specific conflicts, thus making water law a craft of balancing interests and pondering principles. Such is the first mechanism through which the discipline becomes political: against Harmon doctrine-like claims of absolute sovereignty, the equitable utilization principle means, in practice, that no part to a conflict has per se the upper hand. Adjudication in international water law becomes a matter of analyzing contexts and consequences, but legal formalism is frowned upon and law is perceived as means to achieve a greater good.

The Gabcikovo-Nagymaros case ${ }^{6}$ demonstrates how the turn to reasonability infuses politics into legal arguments. In that case, Hungary argued that Czechoslovakia had acted unlawfully by implementing a modification of the works, now widely known as Variant $C{ }^{7}$ The Court, in turn, held that Variant $\mathrm{C}$ amounted to assuming control of the resource, and deprived "Hungary of its right to an equitable and reasonable share of the natural resources of the Danube." Clearly, Czechoslovakia had indeed diverted waters of the Danube. It is unclear, however, why such a diversion could be called "assuming control" and, more importantly, why this alleged control could deprive Hungary of its right to an equitable share of the resource. It is, nonetheless, a perfectly competent application of the principle: its specific boundaries are to be decided by the interpreter, through an assessment of the given context which includes political considerations. And that was, precisely, what the ICJ did.

\footnotetext{
${ }^{4}$ See Case Concerning The Gabèikovo-Nagymaros Project (Hungary/Slovakia), 1997 I.C.J. 7, paras. 85, 147 (Sept. 25).

${ }^{5}$ See ILC, Second Report on The Law Of The Non-Navigational Uses Of International Watercourses, U.N. Doc. A/CN.4/399 (1986), paras. 75-178 (prepared by Stephen C. McCaffrey).

${ }^{6}$ I.C.J., supra note 4.

${ }^{7}$ Id., par. 13 .

${ }^{8}$ Id., par. 85.
} 
We can turn now to the second mechanism of water law politicization: our disciplinary neighbors. By this, I mean the areas of international law that deal with international watercourses in a way that intends to be exhaustive, at least for the purposes of a specific conflict. Regulation of international watercourses is simultaneously reframed as a problem of economic development ${ }^{9}$ and as an environmental issue ${ }^{10}$; as a trade issue ${ }^{11}$ and as a human rights problem. ${ }^{12}$ Furthermore, the notion of water security seems to be gaining popularity, thus making international watercourses a matter of the law of use of force. ${ }^{13}$ Five different legal regimes: one single resource. Our discipline seems to be thus trapped in the maelström of legal fragmentation, which necessarily brings politics into the game.

Indeed, each self-contained regime features a way of understanding conflicts that, in interaction with its particular set of principles and exceptions, ultimately shape the final outcome of a given case. This is not to say that each regime concerned with water is, to use a famous expression, "clinically isolated" from the rest of public international law. ${ }^{14}$ However, it does mean that, at the very least, the choice between regimes implies a conflict between the institutions that embody them, their respective language and expertise. This conflict is, by all standards, of a political nature. And yet, we lack a significant guideline as to which regime is right for a particular case. Consider, for example, the case of the Pulp Mills on the River Uruguay, currently on the ICJ's docket. ${ }^{15}$ The case involves the construction of a pulp mill plant on the Uruguayan side of the river, which Argentina holds is a breach of international law. Surely, such a case is to be decided within the framework provided by the law of international watercourses. But surely, it is also a trade issue. How are we to choose? Think also of the equitable utilization principle, which has been often interpreted to include a certain level of environmental protection, as is made clear by the language of Article 5 of the 1997 Convention. Once again: is that a matter of international water law? Or is it environmental law?

One possible answer is that, facing such complexity, the law of international watercourses should include variables of adjacent disciplines. Thus, a properly holistic view of our craft should include water governance, human rights, trade law, etc. This approach imposes a heavy burden on the water law operator and is, at any rate, an essentially political answer to the question. It makes the implicit decision of choosing the law of international watercourses as the default framework for the discussion, and then complements it with bits and pieces from other disciplines. By the same token, the trade lawyer could argue that all water issues (including transboundary non-navigational use) are problems of trade in goods and services, which can be then enhanced by including some references to the principle of equitable utilization. No distinctively legal answer exists to determine why one of the regimes is

\footnotetext{
${ }^{9}$ See World Bank, Water Resources Sector Strategy: Strategic Directions For World Bank EngageMENT - POLICY PAPER 28114 (2004).

${ }^{10}$ See UNEP, Global International Waters Assessment, Challenges to International Waters Regional Assessments in a Global Perspective (2006).

$"$ See, Introduction to Fresh Water ANd InTERnational Economic LAW, 2 (Edith Brown Weiss, Laurence Boisson de Chazournes \& Nathalie Bernasconi-Osterwalder eds., 2005).

12 See U.N. Econ. \& Soc. Council [ECOSOC], General Comment 15: The Right to Water, U.N. Doc. E/C.12/ 2002/11 (2002).

${ }^{13}$ See Jutta Brunnée \& Stephen J. Toope, Environmental Security and Freshwater Resources: Ecosystem Regime Building, 91 AJL 26 (1997).

${ }^{14}$ See ILC, Fragmentation of International Law: Difficulties arising from the Diversification and Expansion of International Law, U.N. Doc. A/CN.4/L.682 (2006), para. 487 (finalized by Martti Koskenniemi).

${ }^{15}$ Case Concerning Pulp Mills on the River Uruguay (Argentina v. Uruguay), I.C.J. At the time of writing, following the Court Order of September 14 2007, the case was in its reply/rejoinder phase.
} 
preferable. Thus, when we choose our discipline as the starting point of the discussion, we are making a political choice. Such is the second way through which our discipline becomes influenced by its political context.

The final mechanism of politicization is the procedural shape taken by several disputes related to watercourses. Prior notification of activities that may have significant adverse effects on the resource is an obligation under Article 12 of the 1997 Convention, and under several other bilateral agreements concerning transboundary water resources (such as the 1975 Statute of the River Uruguay). In this context, who decides whether a specific project is likely to have a significant adverse effect? That decision falls upon the very state that plans to undertake the project. Each Party to the Convention is the sole judge of whether its plans are likely to have significant adverse effects, being thus reason enough to trigger the notification procedure. To be sure, such uncertainty may be limited by procedures deployed in the absence of notification, such as those contained in Article 18 of the 1997 Convention. However, in that case, once a prudential time of negotiation expires, the interested Party still has the right to make the ultimate decision based on its domestic political variables. Even if there is a serious and independent environmental impact assessment available, the ultimate decision of potential adverse effect is a political call. Such is the third mechanism of water law politicization.

What is there to conclude from these three mechanisms? The first thing is, of course, that the discipline has developed argumentative devices that allow us to deal rationally with its necessary reliance on politics. That is, to my mind, a good thing. By doing so, however, the discipline seems to have created the tools required to definitively give up its independent normative value in the formulation of policy. Indeed, the three mechanisms seem to draw from a theoretical view that understands law as a means to achieve policy goals. And that approach, though not uncommon among policy makers, seems to be a self-defeating strategy if advanced by legal language itself. 
